\title{
Nordiques
}

40 | 2021

Territoires de la migration dans les pays nordiques et baltes

\section{Regime Entanglement in the Emergence of Interstitial Legal Fields: Denmark and the Uneasy Marriage of Human Rights and Migration Law}

Thomas Gammeltoft-Hansen and Mikael Rask Madsen

\section{OpenEdition}

Electronic version

URL: https://journals.openedition.org/nordiques/1518

DOI: 10.4000/nordiques.1518

ISSN: $2777-8479$

Publisher:

Association Norden, Bibliothèque de Caen la mer

Electronic reference

Thomas Gammeltoft-Hansen and Mikael Rask Madsen, "Regime Entanglement in the Emergence of

Interstitial Legal Fields: Denmark and the Uneasy Marriage of Human Rights and Migration Law", Nordiques [Online], 40 | 2021, Online since 02 May 2021, connection on 11 July 2021. URL: http:// journals.openedition.org/nordiques/1518 ; DOI: https://doi.org/10.4000/nordiques.1518

This text was automatically generated on 11 July 2021.

Nordiques 


\title{
Regime Entanglement in the Emergence of Interstitial Legal Fields: Denmark and the Uneasy Marriage of Human Rights and Migration Law
}

\author{
Thomas Gammeltoft-Hansen and Mikael Rask Madsen
}

\section{Introduction}

1 'The Court is not an immigration Appeals Tribunal or a Court of fourth instance.' So spoke the united member states of the Council of Europe ( $\mathrm{COE})$ on the occasion of the 2011 Izmir Declaration - a declaration drafted in the context of the Interlaken reform process of the European Court of Human Rights (ECtHR) kicked off the year before. ${ }^{1}$ The blunt statement was repeated verbatim in 2018 in the first draft of the Copenhagen Declaration, which was adopted as a much-revised version later that year. Although the Danish government argued that it merely deployed what in diplomatic circles is known as "agreed language", this time it caused alarm among many other member states of the $\mathrm{CoE}$ and across civil society organisations. Divorcing human rights from the rights of migrants was simply not acceptable in 2018 - and not the least since the then Danish government had publicly made it a priority to regain sovereign control of its immigration policy. ${ }^{2}$ This issue, and in particular cases related to what were termed 'foreign criminals' and their rights to family life under Article 8 of the European Convention of Human Rights (ECHR) had become a recurrent theme in Danish media and political discourse. Consequently, the then minority government was under significant pressure from its far-right supporters in the Danish People's Party (Dansk Folkeparti) to deliver on the migration issue by pushing back the reach of the ECHR. 
2 These two issues - human rights and migration - have historically had distinct trajectories both in Danish and in European law and politics, but the coupling of the two, we argue, have transformed both. Migration law has gained legal momentum and judicial empowerment from increasingly engaging human rights law and institutions; human rights law has gained legitimacy for its universalist aspirations by developing, albeit slowly, a jurisprudence on non-nationals' rights. ${ }^{3}$ Yet, the coupling has also been politically contentious - at times even explosive - which in turn has challenged both fields of law. From the perspective of international law, establishing accountability for migrant and refugee rights violations has always required a certain degree of adjudicatory exploration. The lack of a dedicated international court or quasi-judicial monitoring mechanism pertaining to the refugee regime has historically led scholars and practitioners to focus on domestic legal venues. Over the past few decades, however, the rights of other categories of migrants have been contested before other legal institutions, invoking other human rights treaties, ${ }^{4}$ as well as e.g. EU law. ${ }^{5}$ While some of these institutions have remained more ambivalent about taking on a larger role in this issue area, ${ }^{6}$ others have more or less embraced the opportunity to fill this judicial vacuum. Indeed, non-refoulement cases today make up the overwhelming majority of pending petitions before the Committee Against Torture. ${ }^{7} \mathrm{New}$ opportunities have further emerged as the result of normative and institutional developments. The CEDAW committee, for example, has recognized an implied prohibition against refoulement and heard individual communications involving refugee authors. ${ }^{8}$ The Committee on the Rights of the Child, which began receiving individual communications only in 2014 , has started to receive complaints related to refugee children. ${ }^{9}$

3 The present article examines the political and legal processes through which human rights and migration law have become confounded - what we in this article more generally refer to as regime entanglement. Regime entanglement implies that different areas of law not only interact but are more fundamentally entwined and mutually impacted. In the case of human rights and migration law, we argue that their mutual interface has fundamentally reshaped both legal fields and produced something relatively new. Human rights is no longer simply a complementary angle into refugee and migration law, but a primary vantage point for both national and international litigation on refugee and migration matters. Nonetheless, this amalgamation of the two fields has simultaneously triggered some of the most significant pushback against international human rights law and adjudication, as the recent Danish proposals to reform the ECtHR exemplify.

4 Although the entanglement of migration law and human rights law is a general European development, in this article we limit ourselves to a study of migration law and human rights and how these two legal regimes have been implemented and have interacted in Danish law and politics. Focusing on the Danish case allows us to provide a situated analysis of how these regimes are negotiated and contested. Denmark is also an interesting case, which represents and in some regards perhaps even epitomises developments also seen in other European countries in respect to the growing politicization of both migration and human rights. While international and European human rights for a long period received limited political attention in Denmark and other European countries, we argue that their emergence as a marker of domestic political controversy is closely linked to the ways in which it they have fused with 
migration law and helped develop rights of migrants in recent years. ${ }^{10}$ Likewise, migration law has moved from being a relatively small subfield of law to taking centrestage in many debates over human rights.

5 The Danish case is a particularly useful entry point for understanding and analysing this process, given the explicitness of the political rhetoric and the scope of legislative amendments which have been tabled. That said, neither of these processes are unique to Denmark and many other European countries have undergone similar transformations, both in terms of their immigration history and experience, and in terms of increasingly restrictive migration politics and policies. Thus, our choice of Denmark as case study is informed by a wish to understand not simply the Danish particularities of this issue, but to use this more limited case to explore a broader phenomenon of consequence to European society in general. Basically, the fusing of migration law and human rights, and the accompanying politico-legal discourses of each field, represent an emblematic case of how the underpinning liberal values of European society - human rights - are challenged and transformed by current changes stemming from both intra- and extra-European mobility.

In this article, we undertake an explorative study of the evolution of the two legal regimes in focus and their gradual entanglement. A key challenge of such an undertaking is that the two fields have developed distinct perspectives on their own histories and specific narratives. We therefore employ a dual perspective, which retains and seeks to bring into conversation the dual construction of the interstitial migranthuman rights legal field with each of its two original pathways. In methodological terms, this double regard entails taking seriously the parallel and at times distinct productions of the emerging interstitial legal field somewhere at the crossroads between the more established regimes of human rights and migration law. ${ }^{11}$ In other words, we employ a double reflexivity towards our object of inquiry in order to unpack the problem of field-specific knowledge production in each of the subfields studied. Such an approach draws on insights from Bourdieusian sociology and its application to the empirical study of transnational legal fields. ${ }^{12}$ Building on that tradition, we seek not only to challenge the tendency to departmentalise legal developments in their field of origin ${ }^{13}$ but also to explore how regime entanglement occurs as empirical developments. The international and European characteristics of our object of inquiry naturally turns the study towards the interface of national and European politics and law of the fields in focus. Moreover, both human rights and migration law have been largely influenced by geopolitical changes affecting both the possibility of agreeing on international regimes and the ebbs and flows of migration. Our study emphasises these common structural changes and conditions in the parallel evolution of the two fields and their eventual intersection. The article is therefore structured in two main sections which explore, respectively, the influence of human rights on migration law and the impact of migration claims on the development of human rights, with a special focus on the ECtHR. In a third and final section, we combine the two perspectives and draw up a set of conclusions. 


\section{National dynamics of regime entanglement and contestation: The case of Denmark}

7 Denmark has often been held up as a liberal frontrunner when it comes to refugee and migrant rights. Denmark chaired the negotiations of the 1951 Refugee Convention and it was the first country to sign and ratify it. Along with other Nordic countries, Denmark has remained an important donor to the UN High Commissioner for Refugees, and a long-standing and active member of its Executive Committee. When economic crisis and new asylum flows led other states to adopt more restrictive policies in regard to foreigners, this political legacy initially led Denmark to introduce its 1983 Aliens Act; at the time claimed to be the 'world's most liberal asylum and migration legislation' by several international observers. ${ }^{14}$ Today, however, this picture has substantially changed. Over the past decades, Denmark has imposed a series of restrictive policies in regard to both asylum and immigration. In 2016, Denmark made international headlines after passing a bill restricting access to family reunification for Syrian refugees up to three years and allowing the police to search refugees and seize their assets. ${ }^{15}$ Following the surge in asylum numbers during the summer of 2015, Denmark ran an anti-refugee ad campaign in Arabic newspapers warning them against going to Denmark. ${ }^{16}$ Later that year, then Prime Minister Lars Løkke Rasmussen suggested that the 1951 Refugee Convention should be revised. ${ }^{17}$

8 Although this political U-turn is hardly unique to Denmark, the Danish case is nonetheless instructive for understanding how domestic political dynamics fundamentally shape states' approach to international law in this area. ${ }^{18}$ Throughout the years, international human rights law has played an important role in the formulation of new immigration legislation - either directly or indirectly. The cornerstone of Denmark's current asylum and immigration policy was laid down with the 1983 Aliens Act. The Act replaced the Foreigners Act that with few changes had been in effect since 1952. The starting point for negotiations over the 1983 Aliens Act was to improve legal guarantees for foreigners, in particular asylum-seekers and those applying for family reunification. At the time, Denmark did not experience a significant influx of refugees or other groups of migrants and asylum recognition rates remained high. Hence, the political motivation for the 1983 Aliens Act was not to establish a substantively more liberal policy, but rather to provide more legal clarity, avoid arbitrary administration of different cases and ensure that Danish law more explicitly set out rights in regard to asylum, family reunification and expulsion. ${ }^{19}$

9 What the drafting process around the 1983 Aliens Act highlights, however, is two distinctly different approaches in terms of how individual states engage with international law. In the legislative drafting committee, two fronts quickly emerged. The majority was led by then Minister of Justice Erik Ninn-Hansen and the conservative government coalition. The minority by members of the opposition and civil society organisations, most notably the Danish Refugee Council. Both sides agreed to include e.g. a positively formulated right to seek asylum; something never codified in the 1951 Refugee Convention but at the international level back then only found in general human rights instruments. ${ }^{20}$ The majority of the committee were concerned, however, that too broadly formulated rights would undermine Denmark's possibility to sufficiently control immigration. To counter this risk, the majority insisted on an 'executive approach', in which administrative competences to issue detailed rules were 
built into the legislation. For example, an emergency brake was proposed to reject asylum-seekers at the border in cases of mass influx and a possibility to deny asylum under certain conditions introduced. Most importantly, the majority's legislative proposal did not contain a legal entitlement to family reunification, but left it to the Ministry of Justice to regulate this administratively depending on factual developments.

10 The minority in the drafting committee conversely pushed for a more "rights-based approach" and argued that too much administrative flexibility not only undermined the legal standing of asylum-seekers and immigrants, it would also enable the government to introduce wide-ranging changes without parliamentary consent. ${ }^{21}$ In a surprising turn of events, and following the mobilisation of a broad range of Danish civil society actors, an alternative proposal drafted by the minority was subsequently adopted by Parliament. The new Act now contained a positive right to family reunification, a right to asylum for so-called "de facto" refugees and a number of legal guarantees in regard to expulsion. The Act also included a verbatim reference to e.g. the refugee definition set out in Article 1a of the 1951 Convention Relating to the Status of Refugees, thereby creating a direct link between national authorities and the new appeals body, the Refugee Appeals Board, to apply and interpret international law.

11 At a more general level, several aspects of the new rights catalogue established may be seen to reflect wider contemporary international human rights law developments beyond the requirements set by international refugee law. The right to family reunification, for instance, was never included in the 1951 Refugee Convention, but rather hinges on interpretation of the general right to private and family life. The 1975 Helsinki Accords helped cement family reunification as a human right, and some sporadic case law from the European Court of Human Rights (ECtHR) on this issue similarly emerged in the mid-1980s. ${ }^{22}$ Similarly, references to both UN and European human rights law regarding expulsion can be found in the preparatory work for the 1983 Aliens Act. ${ }^{23}$ Indirect reference to general human rights law may also be argued to underlie the Act's incorporation of a right to asylum for so-called "de facto" refugees. This category was directed at groups such as conscientious defectors, torture victims, and persons fleeing from either generalised violence or gender-related persecution. All categories that were directly linked to general human rights protections, ${ }^{24}$ but at the time generally considered not to fall within the ambit of the refugee definition set by 1951 Refugee Convention. The act further established that persons granted this form of subsidiary protection were granted rights on par with those afforded to Convention refugees. Last, but not least, the right to family reunification was ensured for both categories of refugees - again moving beyond the strict requirements of international refugee law. The entanglement of international migration law and European human rights law, in other words, was already evident at the national level, at which different standards were synthesised across regimes and issue areas.

12 Notably, however, direct reference to human rights law standards were scant in the negotiations of the 1983 Aliens Act. As explained by one of the drafting committee members, the minority's primary strategy was to rely on existing, liberal Danish practice in these areas. ${ }^{25}$ This choice further reflected the relative importance accorded to different parts of international law. At the time of drafting, the 1951 Refugee Convention was considered a comparatively stronger and more well- 
established starting point for guiding national immigration law, as compared to European human rights law, which had still to develop a substantial body of jurisprudence in this area. ${ }^{26}$ Consequently, the broader catalogue of rights introduced in 1983 were not seen as legal obligations required under European or international human rights law, at best as a generous interpretation of core principles contained within these instruments. ${ }^{27}$

This outlook became important in the subsequent turn towards more restrictive Danish asylum and immigration policy. In 2001, a new right-wing government took power with electoral support from the Danish Peoples Party and this became both a decisive turning point for Danish immigration policy and the beginning of a growing politicisation of international human rights and refugee law. The new government made immigration policy a key priority and saw it as a key priority to reverse the more liberal compromise reached in 1983. In 2002, the hitherto largest suite of amendments to the Aliens Act were thus introduced, with a specific aim to more closely align Danish legislation with a minimum interpretation of relevant international law. ${ }^{28}$ The amendment introduced new restrictions on family reunification and replaced the concept of "de facto refugees" with a right to subsidiary protection called "B-status" that in its formulation directly mirrored Denmark's obligations under Article 3 of the European Convention on Human Rights. ${ }^{29}$ Numerous subsequent amendments driven by the new alliance similarly meant that international human rights law became a more explicit nodal point in both Danish legislation and administrative practice. For example, in 2018 expulsion of foreigners convicted of crime became mandatory unless it "with certainty" violates Denmark's international obligations..$^{30}$ During this period, a more general political shift can further be observed, making a "tough but fair" immigration policy a cross-aisle platform. In particular during the past decade, shifting Social Democratic governments have thus equally implemented new restrictions in regard to e.g. asylum and family reunification and pushed back against international law in this area.

14 In spite of this restrictive turn, however, far from all measures achieved the intended goal of limiting access for asylum-seekers and unwanted immigration to Denmark. A key factor in this regard was the similarly dynamic development of international human rights jurisprudence during this period. Consequently, despite political claims to the contrary, it is far from clear that the abolishment of the "de facto" category in 2002 significantly impacted acceptance rates for asylum applications. Several of the categories covered by this provision had in the meantime been encompassed by developments in either general human rights jurisprudence or dominant interpretations of the 1951 refugee definition. ${ }^{31}$

The most pronounced effect of the 2002 amendment on asylum recognition was for the category of persons fleeing generalised violence, commonly referred to as "war refugees." Up until 2002, the "de facto" concept had been applied to grant asylum to e.g. Somalis fleeing the civil war. At the time of the amendment, this group was not seen to fall within the ambit of Denmark's international obligations under neither the 1951 regime nor general human rights law. ${ }^{32}$ Just two years later, however, the budding harmonisation of EU asylum law introduced a concept of subsidiary protection covering, among other things, "serious and individual threat to a civilian's life or person by reason of indiscriminate violence in situations of international or internal armed conflict. ${ }^{{ }_{33}}$ A notion that the Court of Justice of the European Union (CJEU) later 
confirmed created an obligation beyond the category of people protected by Art. 3 of the European Convention of Human Rights. ${ }^{34}$ That in itself needed not concern Denmark, which maintains a legal opt-out meaning that neither EU asylum law ${ }^{35}$ nor CJEU jurisdiction applies. ${ }^{36}$ In 2011, however, the ECtHR handed down its decision in Sufi and Elmi, applying a very similar interpretation and specifically arguing that the European Convention of Human Rights should offer "comparable protection" to that of European asylum law. ${ }^{37}$ This forced Danish asylum authorities to alter their approach and to reopen a number of already rejected cases. ${ }^{38}$

The growing role of European courts and international human rights bodies in regard to migration issues during these years may similarly be seen to prompt a national response. The Danish case in this sense highlights the difficulty of brokering national sovereignty and international law in an area subject to dynamic interpretation. As the entanglement of migration and human rights law shifts from national legal processes to being driven by international judiciaries, a different kind of politics, centred around a more managerial approach to international legal obligations, has started to take shape. ${ }^{39}$ The Danish government's response to the above-mentioned developments in EU and human rights law came in 2015. A new legal status, titled "temporary protection," was introduced, specifically aimed at persons owed protection as a result of indiscriminate violence - at the time predominantly Syrian refugees. ${ }^{40}$ Compared to other forms of asylum, residence permits based on the temporary protection category are granted for shorter periods and subject to annual review, and associated rights more limited. Most significantly, persons offered temporary protection status will normally only be able to apply for family reunification after 3 years. ${ }^{41}$

For Denmark, the national response to increased international adjudication of asylum and migration law has thus first and foremost been to step up efforts to deter asylumseekers and family reunification. Deterrence policies - defined as measures intended to stymie or prevent migrants and refugees from either arriving at the territory or accessing the asylum system of a prospective destination state - has been a favoured response of developed states from the 1980s onwards. ${ }^{42}$ Denmark has been part and parcel of this development, in some cases clearly inspiring other countries. A particular novelty of the 1983 Aliens Act was the introduction of a 'first country of asylum' clause. Denmark was also the first country to incorporate an explicit legislative provision in regard to 'safe third countries' in 1986 allowing for pre-procedure rejections at the border; a concept which became known as 'the Danish clause' as it was replicated throughout Europe. ${ }^{43}$

For a country like Denmark - located in Northern Europe and with few arrivals at its external EU borders - the bulk of recent deterrence measures apply a more indirect logic, designed to make conditions for asylum-seekers, refugees and migrants less attractive rather than directly limiting who is owed asylum. The 'temporary protection status' is a case in point. On the one hand it formally recognises a right to asylum based on indiscriminate violence in line with international jurisprudence, on the other hand it aims to discourage this type of asylum claims or divert them to other countries by limiting the rights associated with this particular status. Other examples of this kind of indirect deterrence include cutting social benefits for refugees by $50 \%$ and grading child care support and pensions for refugees based on the their length of stay in Denmark. ${ }^{44}$ Legislation has further been adopted granting the police authority to search and seize funds and assets from asylum-seekers in order to cover costs related 
to accommodation and other benefits. ${ }^{45}$ Possibilities to detain asylum-seekers have been expanded, and an option to waive the ordinary, automatic right to habeas corpus for detained asylum-seekers in cases of mass influx. ${ }^{46}$ Fees have finally been introduced in connection with applications for family reunification and permanent residence for refugees. The latter is further subject to new requirements in regard to language and employment and the waiting period for permanent residence extended to six years.

Longitudinal analysis suggest that Denmark's resort to indirect deterrence policies have been, at least partially, effective in reducing asylum arrivals compared to other European countries. ${ }^{47}$ From a legal perspective, it is further worth noting that unlike the refugee regime, the expanded protections offered to asylum-seekers as a matter of general human rights law are not mirrored by a similar rights catalogue specifically governing their status. In other words, while international human rights jurisprudence has placed an expanded obligation upon states in terms of who is owed international protection, none of these instruments were specifically designed with migrants and refugees in mind. States thus retain comparatively more freedom than under the 1951 Refugee Convention in terms of regulating their stay. As a final point, it should be noted that not only international institutions, but also national courts and specialised judicial bodies have taken on a key role in translating and brokering interpretations of international human rights law into domestic practice. In 2017, following heated Danish political debates about European human rights law limiting the ability to deport criminally convicted foreigners, the Danish Institute of Human Rights conducted an analysis of domestic jurisprudence and its implementation of ECtHR case law. It concluded that Danish courts could lawfully pursue a more restrictive approach in regard to expulsion cases, while still staying within the confines of the evolving jurisprudence of the ECtHR. ${ }^{48}$ Similarly, the Danish Refugee Appeals Board has repeatedly aligned Danish asylum practice with relevant developments in the jurisprudence of the CJEU. ${ }^{49}$ Although the board carefully notes that Denmark is neither bound by EU's asylum directives nor interpretations thereof, EU jurisprudence thus nonetheless comes to exercise a degree of normative force on Denmark through its interpretation and harmonisation of state practice of other European states.

In sum, the Danish case shows how the entanglement between migration law and human rights law has emerged first at the national level and secondly at the international level. Historically, this conflation was less of an issue since persons offered complementary or "de facto" protection status were automatically offered the same benefits and rights as refugees owed protection under the 1951 Refugee Convention. In the current political climate, however, and in light of the reduced national manoeuvre room resulting from growing international judicialisation, the asymmetry between the ambit of who is owed protection and the substantive rights governing their stay is increasingly exploited as a way for shifting Danish governments to manage regime entanglement at the international level. This does not mean that current suite of indirect deterrence measures will not equally be subject to similar litigation before different international human rights bodies and courts. The challenge facing such cases, however, is that the relevant human rights issues - e.g. nondiscrimination or the right to family life - were never designed specifically with migrants or refugees in mind. As a result, they typically remain subject to proportionality assessments and/or long-standing precedents sanctioning differential 
treatment between nationals and non-nationals. Even where litigation is successful, states might further respond to international jurisprudence through post-judgment adaptation strategies. For example, in 2016 the ECtHR found a key element of Denmark's restrictive family reunification policy to constitute indirect discrimination based on ethnic origin. ${ }^{50}$ The immediate response by the Danish government was to expand the so-called "attachment criteria" to also apply to Danish citizens, before subsequently replacing it with a new "integration requirement" considered to achieve a similar result while simultaneously taking the new ECtHR precedent into account. ${ }^{51}$

\section{The other side of the coin: European human rights law meets migration}

As the above review of the Danish migration regime and its relationship to international and European human rights standards illustrates, migration law, also more generally, has become influenced by human rights law and principles. Today, it is difficult to imagine migration law without also considering a host of human rights issues as developed by specialised human rights courts and bodies. Vice versa, migration and refugee law scholarship speak of a "human rights turn." With significant implications for both theory and practice..$^{52}$ Within refugee law, for example, international human rights law has served both as a framework through which to interpret core obligations, and as a wider catalogue of substantive rights creating other normative entry points against restrictive policies or additional protections for certain groups of refugees. This includes, for instance, the right to leave as established in Art. 12 of the Covenant on Civil and Political Rights ${ }^{53}$ and the special protection afforded to children and minors. ${ }^{54} \mathrm{~A}$ number of studies have further linked interpretation of the non-refoulement obligation and other core rights within the Refugee Convention to the burgeoning literature on extraterritorial human rights jurisdiction. ${ }^{55}$

There is, in other words, little doubt that human rights have encroached on migration law and are today more or less an integral part of migration law. Paraphrasing MarieBénédicte Dembour, migrants have become humans as in human rights. But as Dembour documents in her analysis, this process of providing human rights status to migrants - or what we describe as regime entanglement - has been both long and cumbersome and remains incomplete. ${ }^{56}$ Indeed, if we view the opposite side of our object of inquiry, that is, how human rights have become influenced by migration law, we can observe what might best be described as a reluctant engagement, at least historically. This section tackles this complex process when seen from the perspective of human rights. Due to space restrictions, we limit ourselves to some key turning points with regard to the ECtHR, arguably the most central institution in this context, and particularly as it pertains to the Danish case.

Historically, it is not an overstatement to claim that the ECtHR and its underlying Convention was not written with the purpose of generating a vast catalogue of migrant rights. Specialised regimes regarding refugees and stateless persons were simultaneously being developed at the UN level, and the main goal of the new European human rights regime, as argued elsewhere, was geopolitical. ${ }^{57}$ The idea was to establish a common system that could sound the alarm if genuine democracy was threatened within the member states; the real fear was Soviet expansionism into Western Europe. ${ }^{58}$ 
As a response, a robust institutional bulwark, consisting of the European Court of Human Rights (ECtHR or Court), the European Commission of Human Rights (EComHR) and the Committee of Ministers of the Council of Europe ( $\mathrm{CoE})$, was put in place to protect the free world and its values of rule of law, democracy and human rights. ${ }^{59}$ In addition, the ECHR and its resulting institutions were marked by the fact that a number of the major CoE member states such as the United Kingdom and France were empires in decline and very attuned to the risks that decolonization entailed in terms of migration.

The original ECHR was, on the one hand, open towards protecting the rights of people residing in Europe and, on the other, closed towards claims coming from the overseas territories of European powers. As to the former, the protections offered by the ECHR were cosmopolitan in nature and applied to everyone within the jurisdiction of the member states (ECHR Articles 1) and, therefore, non-national citizens were also protected. This opening was mitigated by the inclusion of the so-called colonial clause (Article 56), which reflected prevalent colonial sentiments of the time and stipulated that the colonial state could choose when and if the colonised should be entitled access to the ECHR system. In other words, rather than having an automatic universal application across the empires, the jurisdictional reach of the ECHR could only be extended by opt-ins decided in the imperial capitals. All in all, the system, which was set up, clearly favoured intra-European protection. ${ }^{60}$ Or, as Marie-Bénédicte Dembour puts it, '[...]migrants were hardly a consideration in the newly created human rights scheme. The Convention was not meant to sustain their rights. ${ }^{61}$

If we look at the many different cases lodged with the European Commission in the first decades after its establishment in 1955, claims involving migrants were summarily dismissed as inadmissible or found to have no legal merit. ${ }^{62}$ While this was arguably a general trend at the early ECHR system, ${ }^{63}$ the first real migration cases to reach the court was in the mid-1980s. At this point, the Court had already established itself as the de facto supreme court of human rights matters in Europe through legal development in many other areas of human rights law. ${ }^{64}$ Hence, the discreet turn towards migration law in Strasbourg occurred rather late, and generally after the member states had started developing their own legislation in this area, as the Danish case detailed in the previous section illustrates. Analysis of the first ECtHR judgments within this category suggests that the Court was hardly an open door for migration-related claims, but consistently insisted on a minimalistic approach that left CoE states rather free to police entrance into their territories as long as conduct at the borders complied with Convention standards. ${ }^{65}$ Questions related to family reunification and foreigners' rights within the CoE were still far away. ${ }^{66}$

But things started gradually changing. One area where the legal construction of the Convention system allowed for the development of jurisprudence was with regard to the expulsion of migrants. Since they already resided within the territory of the state, expulsion decisions made by public authorities had to be balanced by Convention rights, notably the right to personal and family life enshrined in Article 8 ECHR and the prohibition of torture and inhuman and degrading treatment provided in Article 3. Regarding the latter, the relevant jurisprudence was initially developed not via migrant cases but in the context of the possible extradition of a young German to the United States, where he faced a murder trial and potentially capital punishment. The Court found that the risk of the 'death-row phenomenon' would violate Article 3 as it 
constituted inhuman and degrading treatment. ${ }^{67}$ This high-profile and much mediatized judgment was celebrated as a clear European stance on capital punishment, yet it also introduced an indirect non-refoulement principle into the Convention that opened up for subsequent expansion into migrants' rights only a few years later. ${ }^{68}$ As to Article 8 and the protection of family life, the story is different. In 1988 the ECtHR delivered its first judgments concerning the expulsion of foreign criminals.$^{69}$ From the get-go it was clear that the Court was divided on how to treat long-term residents who were non-citizens (e.g. second generation immigrants) and the resulting case law has been marked by a case-by-case logic until the 2001 Boultif case, which set out a set of core principles. ${ }^{70}$ In recent years, after pressure from for instance the UK, there is arguably a reverse tendency to once again lower protection standards. ${ }^{71}$

This is also where the Danish interface with the ECtHR enters the picture. Denmark's engagement with the ECtHR was originally marked by an internationalist outlook, evidenced both in inter-state cases launched against other CoE member states and the fact that the country was not found in violation of the Convention until 1989 regardless of being under the jurisdiction of the ECtHR since 1959.72 The domestication of the ECHR and the jurisprudence of the ECtHR happened not least at the intersection of migrant claims and human rights. As in other western European countries, the ECtHR simply offered a new and somewhat promising avenue for challenging the legislation and decision-making of the domestic authorities in the area of migration claims. As noted in the previous section, there are several direct examples of how this challenge via the ECtHR led to reforms and adaptations of existing Danish law and administrative practice. But it is also in this precise interface that the increasingly contentious nature of migration issues had a spill-over effect and more generally politicized human rights law and adjudication. In the Danish case, it literally became part of the government programme to find ways to limit the effects of the ECtHR on Danish immigration policy. 73

A number of high-profile cases emerged, where the Danish Supreme Court ruled that Article 8 protection of family life hindered expulsion. This triggered strong responses from a growing number of Danish politicians, initially from the right but eventually also including the centre-left. They viewed the ECtHR/ECHR as unduly protecting an undesired minority of foreign criminals to a degree that challenged the majority's political mandate. In response, the Danish government in 2016 publicly announced that it would "bring the Convention back to its original core' ${ }^{74}$; a clear retrograde objective seeking to turn back the clock to precisely the period before the ECtHR had developed its jurisprudence regarding migrant rights. This political programme, however, was short-lived due to opposition in other member states and the mobilisation of civil society organisations.

When Denmark took over the Presidency of the CoE in 2017 a new attempt was made. Following negotiations with the member states, the Danish government went ahead and published a draft Copenhagen Declaration, which caused controversy across Europe. Speaking mainly to a domestic agenda of inflamed sentiments towards the ECtHR, the draft, for example, singled out immigrants and asylum-seekers, and generally called on the ECtHR to be deferential vis-à-vis the member states. ${ }^{75}$ The text was subsequently redrafted and moderated and eventually resulted in a diplomatically acceptable compromise - containing no specific references to the Court's approach in migration cases. Although the Danish government had failed in terms of its set 
objective to separate migration and human rights, it had nonetheless succeeded in hammering out that the fusion of these two areas of international law is one of the most controversial aspects of contemporary politics.

\section{Conclusion}

31 This article has attempted to provide a contextualised understanding of how regime entanglement can be understood from the vantage point of the national level. As pointed out by other scholars, regime entanglement and resulting new assemblages are rarely smooth. ${ }^{76}$ Due to the strategizing of states, the relative incompatibility of different legal regimes and the interests of international institution to protect themselves against getting embroiled in megapolitical issues, interstitial legal fields such as the one studied here remain somewhat non-consolidated and open for critique from multiple angles. As the Danish example shows, such political critique does not always translate into legal transformations at the international level. However, it means that interstitial legal fields lack some of the traits normally associated with more autonomous legal fields, such as legal predictability and legal authority. The migration-human rights field is therefore likely to remain subject to political gaming zones of law, where different national powers seek to set the direction of legal evolution by putting pressure on and pushing back against the international level.

Our study has deliberately applied a double regard perspective to analysing the national and international evolution of migration and human rights. This approach enables the unpacking of the different impacts of regime entanglement in each dimension. Within migration and refugee law, for example, the so-called "human rights turn" has had immense impact, expanding frameworks of argumentation and providing new and important avenues for international adjudication. Several key cases relating to refugee and migrant rights have been lodged before regional human rights courts such as the ECtHR, the conclusion of which have time and time again forced states to either abandon or substantially adjust national migration policies. ${ }^{77}$ Last, but not least, governments' own interpretation of international human rights law has been argued to pre-emptively block earlier proposals to outsource asylum processing. ${ }^{78}$ In recent years, different UN human rights treaty bodies have further become increasingly involved in individual petitions relating to asylum and immigration issues. Indeed, non-refoulement cases today make up the overwhelming majority of pending petitions before the Committee Against Torture ${ }^{79}$ While human rights may thus be said to have energized migration law, in the reverse scenario the relationship is more ambivalent. It is clear that institutions such as the ECtHR have had a hard time coming to terms with how to deal with migrant issues in its jurisprudence, partly because the system was originally designed not to directly address such claims. Only very gradually, and often accompanied by political controversy, has the ECtHR engaged these issues. Today, we can identify a distinct case law on non-refoulement, family reunification, treatment of migrants at borders, etc. Yet, it is a jurisprudence built on deriving rights from generally defined provisions such as the right to family life or the prohibition against torture. This has made it an easy target for critics who have repeatedly pointed out that these developments were never foreseen by the drafters..$^{80}$ While such claims to interpretative originalism are obviously at odds with the dynamic interpretative style 
of the ECtHR since the late 1970s, it nevertheless adds fuel to the fire of the politics of legal regime entanglement in the case of migration law and human rights.

\section{NOTES}

1. On the reform process, see for example Lize R Glas, "From Interlaken to Copenhagen: What Has Become of the Proposals Aiming to Reform the Functioning of the European Court of Human Rights?," in Human Rights Law Review 20, volume 20, $\mathrm{n}^{\circ} 1$ (2020).

2. Mikael Rask Madsen, "Two Level Politics and Backlash against International Courts: Evidence from the Politicisation of the European Court of Human Rights," The British Journal of Politics and International Relations, $\mathrm{n}^{\circ}$ 4, 2020.

3. Marie-Bénédicte Dembour, When Humans Become Migrants: Study of the European Court of Human Rights with an Inter-American Counterpoint, Oxford, Oxford University Press, 2015.

4. Ruth Rubio-Marin, Human Rights and Immigration, Oxford, Oxford University Press, 2014.

5. Cathryn Costello, The Human Rights of Migrants and Refugees in European Law, Oxford, Oxford University Press, 2015.

6. Vasiliki Kosta \& Bruno de Witte, "Human Rights Norms in the Court of Justice of the European Union”, in Martin Scheinin, ed., Human Rights Norms in 'Other' International Courts, Cambridge, Cambridge University Press, 2019, p. 263-286; Moritz Baumgärtel, Demanding Rights: Europe's Supranational Courts and the Dilemma of Migrant Rights, Cambridge, Cambridge University Press, 2019.

7. Başak Çali \& Stewart Cunningham, "A Few Steps Forward, a Few Steps Sideways and a Few Steps Backwards: The CAT's Revised and Updated GC on Non-Refoulement", in EJIL: TALK!, March 20th 2018, https://www.ejiltalk.org/part-1-a-few-steps-forward-a-few-steps-sideways-and-afew-steps-backwards-the-cats-revised-and-updated-gc-on-non-refoulement (Last visited March 4th 2021).

8. UN Committee on the Elimination of Discrimination Against Women (CEDAW), General Recommendation No. 32: Gender-Related Dimensions of Refugee Status, Asylum, Nationality and Statelessness of Women CEDAW/C/GC/32, 2014.

9. CRC, N.B.F. v. Spain CRC/C/79/D/11/2017, September 27th 2018.

10. Jonas Christoffersen \& Mikael Rask Madsen, "The End of Virtue? Denmark and the Internationalisation of Human Rights," in Nordic Journal of International Law, volume 80, $\mathrm{n}^{\circ} 3$, January 2011, p. 257-277.

11. See for comparative methodological approaches: Yves Dezalay and Mikael Rask Madsen, "La Construction Européenne au Carrefour du National et de L'international," Les formes de l'activité politique. Eléments d'analyse sociologique XVIIIe-XXe siècle, Paris, PUF, 2006; Antoine Vauchez, "Interstitial Power in Fields of Limited Statehood: Introducing a "Weak Field" Approach to the Study of Transnational Settings," in International Political Sociology, volume 5, n 3, 2011.

12. Mikael Rask Madsen, "Reflexivity and the Construction of the International Object: The Case of Human Rights," in International Political Sociology, volume 5, n 3, 2011, p. 259-275; Yves Dezalay \& Mikael R. Madsen, "The Force of Law and Lawyers: Pierre Bourdieu and the Reflexive Sociology of Law", in Annual Review of Law and Social Science, volume 8, 2012, p. 433-452.

13. Byrne, Rosemary, and Thomas Gammeltoft-Hansen, "International Refugee Law between Scholarship and Practice", in International Journal of Refugee Law, volume 32, n 2, 2020, p. 181-199. 
14. Interview with former executive staff of the Danish Refugee Council.

15. Charles Duxbury, "Denmark Considers Seizing Valuables From Migrants", in The Wallstreet Journal, January 13th 2016, https://www.wsj.com/articles/denmark-debating-seizing-valuablesfrom-migrants-1452689275 (Last visited March 4th 2021).

16. "Denmark publishes anti-refugee ad campaign", in The Local, September 7th 2015, http:// www.thelocal.dk/20150907/denmarks-anti-refugee-ads-published-in-foreign-papers (Last visited March 4th 2021).

17. Patrick Kingsley, "UN backlash against call to scale back Geneva convention on refugees", in The Guardian, January 6th 2016, http://www.theguardian.com/world/2016/jan/06/un-backlashagainst-call-to-scale-back-geneva-convention-on-refugees (Last visited March 4th 2021).

18. This is further conceptualised in Madsen, "Two Level Politics and Backlash against International Courts".

19. Anne Brøcker, 2006, "Udlændingelovgivning i Danmark 1983-86: Faktorer i den politiske beslutningsproces.", in Politica, volume 22, p. 332-345.

20. For example, Article 14 of the Universal Declaration of Human Rights. On the relationship between this article and the non-refoulement principle set out in the 1951 Refugee Convention, see Thomas Gammeltoft-Hansen and Hans Gammeltoft-Hansen. "The Right to Seek Revisited: On the Un Human Rights Declaration Article 14 and Access to Asylum Procedures in the Eu." in European Journal of Migration and Law 10, $n^{\circ} 4,2008$, p. 439-459.

21. Brøcker, "Udlændingelovgivning i Danmark 1983-86", p. 338.

22. See further Atle Grahl-Madsen, "Immigration and Human Rights: International Dimensions" in Defense of the Alien, $\mathrm{n}^{\circ} 8,1985$, p. 122-129.

23. Report ("Betænkning") 968/1982, pp. 43-44. Earlier reference to human rights standards can similarly be found in Danish administrative practice leading up to the adoption of the 1983 Aliens Act. See notably Executive Order ("Bekendtgørelse") 196/1980, and Report ("Betænkning") No. 882/1979.

24. Notably Articles 18 and 12 of the International Covenant on Civil and Political Rights.

25. Interview with former member of the legislative drafting committee, September 2020. On the development of human rights jurisprudence in this area, see further below.

26. Ibid.

27. Ibid.

28. Kim U. Kjær, "The Abolition of the Danish De Facto Concept", in International Journal of Refugee Law, volume 15, $\mathrm{n}^{\circ} 2,2003$, p. 254-275.

29. Legislative amendment 365, June 6th 2002.

30. Article 24(b), legislative amendment 469, May 14th 2018.

31. Kjær, "The Abolition of the Danish De Facto Concept"; Jesper Lindholm, Danske Asylafgørelser, Copenhagen, Jurist- og Økonomiforbundet, 2014.; See more generally Thomas GammeltoftHansen, "Evolutions in International Refugee Law." Inaugural professorial lecture, Faculty of Law, University of Copenhagen, March 12th 2019.

32. Lindholm, "Danske Asylafgørelser".

33. Council Directive 2004/83/EC of 29 April 2004 on minimum standards for the qualification and status of third country nationals or stateless persons as refugees or as persons who otherwise need international protection and the content of the protection granted, Art. 15(c).

34. CJEU, Case C-465/07, Meki Elgafaji and Noor Elgafaji v. Staatssecretaris van Justitie, Grand Chamber, 2009, ECR 1-921; 2009, 21 IJRL 297-307. See Roger Errera, "The CJEU and Subsidiary Protection: Reflections on Elgafaji - and After", International Journal of Refugee Law, volume 23, $\mathrm{n}^{\circ} 1$, March 2011, 93-112.

35. Denmark is nonetheless member of the EU Dublin system, and applies the Dublin and Eurodac regulations based on an inter-governmental agreement with the EU. 
36. Agreement between the European Community and the Kingdom of Denmark on the criteria and mechanisms for establishing the State responsible for examining a request for asylum lodged in Denmark or any other Member State of the European Union and "Eurodac" for the comparison of fingerprints for the effective application of the Dublin Convention, OJ L66, 8.3.2006, p. 38.

37. Sufi and Elmi $v$ United Kingdom, applications 8319/07 and 11449/07, European Court of Human Rights, 28 June 2011, par. 226. Like Denmark, the United Kingdom retains an opt-out to most parts of the EU asylum acquis, and the applicants could therefore not rely on the precedent set by the Court of Justice of the European Union in this regard.

38. Danish Refugee Appeals Board, "Hjemvisning af sager vedr somaliske statsborgere," 15 December 2011.

39. Thomas Gammeltoft-Hansen, "Creative legal thinking and the evolution of international refugee law", in Lakimies, volume 14, $\mathrm{n}^{\circ} 1,2014$, p. 99-104.

40. Legislative amendment 153, 18 February 2015.

41. This restriction has itself been challenged for violating the right to family life. In 2017, the Danish Supreme Court held that the measure did not violate Denmark's obligations under international human rights law (Supreme Court, case 107/2017, November 6th 2017). At the time of writing, the case is pending before the Grand Chamber of the ECtHR (M.A. v. Denmark (Appl. $n^{\circ}$ 6697/18). European Court of Human Rights, Press Release, ECHR 397 (2019). 20 November 2019).

42. Thomas Gammeltoft-Hansen \& Nikolas Feith Tan, "The End of the Deterrence Paradigm? Future Directions for Global Refugee Policy", in Journal of Migration and Human Security, volume 5, $n^{\circ} 1$, August 2017, p. 28-56.

43. Matthew Hunt, "The Safe Country of Origin Concept in European Asylum Law: Past, Present And future" in International Journal of Refugee Law, volume 26, $n^{\circ}$ 4, December 2014, p. 500-535.

44. Amendment to the Danish Aliens Act, Law No. 1000, August 30th 2015.

45. The authorities may confiscate funds or assets estimated to have a worth above DKK 10.000 (approximately EUR 1.350). According the guidance note, personal assets with a particular sentimental value, such as wedding rings or religious artifacts, are exempted. Amendment to the Danish Aliens Act, Law No. 102, February 3rd 2016.

46. Amendment to the Danish Aliens Act, Law No. 1273, November 20th 2015.

47. Thomas Gammeltoft-Hansen, "Refugee Policy as 'Negative Nation Branding': The Case of Denmark and the Nordics" in Danish Foreign Policy Yearbook, 2017, p. 99-125.

48. Institut for Menneskerettigheder, "Udvisning Af Kriminelle Udlændinge” (København, 2017). See further Thomas Gammeltoft-Hansen \& Sarah Scott Ford, "Danish Immigration Law," in Peter Aagaard Nielsen \& Jesper Olsen, Constitutional and Administrative Law in Denmark (Copenhagen, Hans Reitzel, 2021).

49. This can be seen in regard to e.g. the profiling requirement previously applied in LGBT and sur place religious conversion cases. Both have been successfully challenged before the CJEU and in both cases the Danish Refugee Appeals Board cited this case law as part of the reasoning for a change in practice. See Annual Report of the Refugee Appeals Board 2012, p. 214; Annual Report of the Refugee Appeals Board 2013, p. 338.

50. Biao v. Denmark, European Court of Human Rights, Appl. $n^{\circ}$ 38590/10, 24 May 2016.

51. Gammeltoft-Hansen \& Scott Ford, "Danish Immigration Law".

52. Ruth Rubio-Marin, Human Rights and Immigration, Oxford, Oxford University Press, 2014.

53. Vladislava Stoyanova \& Elspeth Guild, "The Human Right to Leave Any Country: A Right to Be Delivered", European Yearbook on Human Rights, August 2018, p. 373-394; Colin Harvey \& Robert P. Barnidge Jr, "Human Rights, Free Movement, and the Right to Leave in International Law", in International Journal of Refugee Law, February 2007, p. 1-21

54. Jason Pobjoy, The Child in International Refugee Law, Cambridge, Cambridge University Press, 2017. 
55. Bernard Ryan \& Valsamis. Mitsilegas (eds), Extraterritorial Immigration Control, The Hague, Brill, 2010; Thomas Gammeltoft-Hansen, Access to Asylum: International refugee law and the globalisation of migration control, Cambridge, Cambridge University Press, 2011; Maarten den Heijer, Europe and Extraterritorial Asylum, Oxford, Hart, 2012; Cathryn Costello, The Human Rights of Migrants and Refugees in European Law, Oxford, Oxford University Press, 2015; Violeta Moreno-Lax, Accessing Asylum in Europe: Extraterritorial Border Controls and Refugee Rights under EU Law, Oxford, Oxford University Press, 2017.

56. Dembour, "When Humans Become Migrants".

57. Mikael Rask Madsen, "From Cold War Instrument to Supreme European Court: The European Court of Human Rights at the Crossroads of International and National Law and Politics", Law \& Social Inquiry, volume 32, $\mathrm{n}^{\circ} 1$, March 2007, p. 139-143.; Andrew Moravcsik, "The Origins of Human Rights Regimes: Democratic Delegation in Postwar Europe," in International Organization, volume $54, \mathrm{n}^{\circ} 2$, July 2000 , p. 217-252.

58. Ed Bates, "The Birth of the European Convention on Human Rights and the European Court of Human Rights", The European Court of Human Rights between Law and Politics, ed. Jonas Christoffersen and Mikael R. Madsen (Oxford, Oxford University Press, 2011), 21; A. W. Brian Simpson, Human Rights and the End of Empire: Britain and the Genesis of the European Convention, Oxford, Oxford University Press, 2004, p. 346-347.

59. The project also had its roots in national political transformations, notably the emergence of more powerful socialist and communist parties in the aftermath of the Second World War. See generally Marco Duranti, "Curbing Labour's Totalitarian Temptation: European Human Rights Law and British Postwar Politics," in Humanity: An International Journal of Human Rights, Humanitarianism, and Development, volume 3, $\mathrm{n}^{\circ}$ 3, 2012.

60. See generally on the politics of the colonial clause in Simpson; Mikael Rask Madsen, La Genèse De L'europe Des Droits De L'homme: Enjeux Juridiques Et Stratégies D'etat (France, Grande-Bretagne et Pays Scandinaves, 1945-1970), Strasbourg, Presses universitaires de Strasbourg, 2010.

61. Dembour, "When Humans Become Migrants.", p. 2.

62. Ibid.

63. Mikael Rask Madsen, "Legal Diplomacy - Law, Politics and the Genesis of Postwar European Human Rights," in Human Rights in the Twentieth Century: A Critical History, ed. Stefan Ludwig Hoffmann, Cambridge, Cambridge University Press, June 2010, p. 62-82.

64. Mikael Rask Madsen, "The Challenging Authority of the European Court of Human Rights: From Cold War Legal Diplomacy to the Brighton Declaration and Backlash," Law \& Contemporary Problems, volume 79, n 1, March 2016, p. 141-178.

65. For example, racial discrimination in border control was established as a violation of migrants' rights in a very early case. See East African Asians v. The United Kingdom, Commission Report adopted December 14th 1973.

66. The term family reunification is first used in the case Abdulaziz, Cabales and Balkandali v. the United Kingdom , appl. 9214/80, 9473/81 and 9474/81, ECtHR May 28th 1985.

67. Soering v. the United Kingdom, appl. 14038/88, ECtHR July 7th 1989.

68. Mikael Rask Madsen, "The Challenging Authority of the European Court of Human Rights".

69. Berrehab v. the Netherlands, appl. 10730/84, ECtHR, 21 June 1988.

70. Boultif v. Switzerland, appl. 54273/00, ECtHR August 2nd 2001.

71. Laurence Helfer and Erik Voeten, "Walking Back Human Rights in Europe?," European Journal of International Law (forthcoming 2020).

72. Christoffersen \& Madsen, "The European Court of Human Rights between Law and Politics".

73. Lars Løkke Rasmussen, Anders Samuelsen, and Søren Pape Poulsen, "Regeringsgrundlag. For Et Friere, Rigere Og Mere Trygt Danmark", Copenhagen, Prime Minister's Office, 2016. 
74. Quoted in Jakob Mchangama, "Regeringen Vil Begrænse Menneskerettighedernes Rækkevidde. Det Kan Faktisk Være I Menneskerettens Interesse," Zetland, December 15th 2016. 75. See generally Madsen, "Two Level Politics and Backlash against International Courts".

76. Karen J Alter and Kal Raustiala, "The Rise of International Regime Complexity," Annual Review of Law and Social Science 14, 2018, p. 229-249. See more generally Tanja Aalberts and Thomas Gammeltoft-Hansen, The Changing Practices of International Law, Cambridge University Press, 2018. 77. For a range of examples, see Thomas Gammeltoft-Hansen, "The Role of International Refugee Law in Refugee Policy." in Journal of Refugee Studies, volume 27, nº 4, 2014, p. 574-595.

78. Mark Garlick, "The EU Discussions on Extraterritorial Processing”, in International Journal of Refugee Law, n¹8, September 2006, p. 601-630; Gregor Noll, "Visions of the Exceptional: Legal and Theoretical Issues Raised by Transit Processing Centres and Protection Zones", European Journal of Migration and Law, January 2003, p.303-341. See also Netherlands Advisory Committee on Migration Affairs, "External Processing: Conditions Applying to the Processing of Asylum Applications Outside the European Union," in (Advisory Report No 32, 2010) (2010).

79. Başak Cali, "A few steps forward, a few steps sideways and a few steps backwards: The CAT's revised and updated GC on Non-Refoulement", EJIL:Talk March 20th 2018. https:// www.ejiltalk.org/part-1-a-few-steps-forward-a-few-steps-sideways-and-a-few-steps-backwardsthe-cats-revised-and-updated-gc-on-non-refoulement (Last visited March 4th 2021).

80. In the Danish context, see Anders Henriksen, "EMRK, den Nationale Interesse Og det Danske Formandskab for Europarådet," (Copenhagen, Justitia, 2017).

\section{ABSTRACTS}

This article examines the political and legal processes through which human rights and migration law have become confounded - what we in this article more generally refer to as regime entanglement. Regime entanglement implies that different areas of law not only interact but are more fundamentally entwined and mutually impacted. Human rights and migration have historically had distinct trajectories in European law and politics, but the recent coupling of the two, we argue, have transformed both. Migration law has gained legal momentum and judicial empowerment from increasingly engaging human rights law and institutions; human rights law has gained legitimacy for its universalist aspirations by developing, albeit slowly, a jurisprudence on non-nationals' rights. Yet, the coupling has also been politically contentious - at times even explosive - which has in turn challenged both fields of law. Although this entanglement is a general European development, the article applies a more situated approach, using Denmark as a case for understanding how these two legal regimes have been implemented and interacted in national law and politics.

Cet article examine les processus politiques et juridiques par lesquels les droits de l'homme et le droit de la migration ont été confondus - nous l'appellerons plus généralement ici «l'enchevêtrement des régimes». L'enchevêtrement des régimes implique que les différents domaines du droit non seulement interagissent, mais soient plus étroitement liés et s'influencent mutuellement. Les droits de l'homme et le droit de la migration ont historiquement eu des trajectoires distinctes dans le droit et la politique européenne, mais le récent couplage des deux a transformé l'un et l'autre. Le droit de la migration a acquis un élan juridique et une autonomisation judiciaire grâce à l'engagement croissant du droit et des institutions des droits 
de l'homme ; les droits de l'homme ont acquis une légitimité dans leurs aspirations universalistes en développant, quoique lentement, une jurisprudence sur les droits des non-ressortissants. Le couplage des deux droits a cependant été politiquement controversé - parfois même explosif - ce qui a remis en cause les deux domaines du droit. Bien que cet enchevêtrement participe d'une dynamique européenne globale, l'article applique une approche plus localisée, utilisant le Danemark comme un cas d'étude pour comprendre comment ces deux régimes juridiques ont été mis en œuvre et ont interagi dans le droit et la politique à l'échelle nationale.

\section{INDEX}

Mots-clés: migration, droit de la migration, droits de l'homme, Danemark

Keywords: migration, human rights, Denmark

\section{AUTHORS}

\section{THOMAS GAMMELTOFT-HANSEN}

Professor WSR in Migration and Refugee Law, iCourts, Faculty of Law, University of Copenhagen

\section{MIKAEL RASK MADSEN}

Professor of Law and Director of iCourts, Faculty of Law, University of Copenhagen. This research is funded by the Danish National Research Foundation Grant No. DNRF105 and conducted under the auspices of the Danish National Research Foundation's Centre of Excellence for International Courts (iCourts) 